\title{
Wastewater-Based Epidemiology of Cocaine in the Brazilian Federal District: Spatial Distribution, Weekly Variation and Sample Preservation Strategies
}

\author{
Fernando F. Sodré, ${ }^{*, a}$ Rafael S. Feitosa, ${ }^{a}$ Wilson F. Jardim ${ }^{b}$ and Adriano O. Maldaner ${ }^{c}$ \\ anstituto de Química, Universidade de Brasília, 70910-000 Brasília-DF, Brazil \\ ${ }^{b}$ Instituto de Química, Universidade Estadual de Campinas, PO Box 6154, \\ 13083-970 Campinas-SP, Brazil \\ 'Instituto Nacional de Criminalística, Departamento de Polícia Federal, \\ SAIS Quadra 07 Lote 23, 70610-200 Brasília-DF, Brazil
}

\begin{abstract}
The distribution of consumed cocaine in the Brazilian Federal District (FD) was estimated using the wastewater-based epidemiology (WBE) approach. Sewage samples from eight wastewater treatment plants were analyzed for cocaine (COC) and benzoylecgonine (BE) using solid-phase extraction followed by liquid chromatography-mass spectrometry. The highest per capita consumption was noticed for the northern area of the Brazilian Capital (1162 mg day-1 $\left.1000 \mathrm{inh}^{-1}\right)$ being $32 \%$ higher than the average consumption rate of the investigated region. In this area, a day-to-day investigation revealed an average cocaine consumption of $1800 \mathrm{mg} \mathrm{day}^{-1} 1000 \mathrm{inh}^{-1}$ during the weekend, i.e., more than 50\% higher than weekdays. An annual street-grade cocaine load of about 2 ton was estimated for the FD considering previous information on the actual purity of seized street drugs as well as consumers between 15 and 64 years old. Sample preservation strategies were also investigated in order to expand the WBE approach to other Brazilian areas. Sample acidification to $\mathrm{pH} 2.0$ presented the smallest relative errors for COC $(+11 \%)$ and $\mathrm{BE}$ $(-4 \%)$ after a period of three days under typical transport conditions practiced by the Brazilian national postal service.
\end{abstract}

Keywords: illicit drugs, cocaine use, WBE, sample preservation, consumption estimates

\section{Introduction}

Cocaine and its metabolites are commonly found in wastewater due to human urinary excretion or even through direct drug disposal (accidentally or not) in the sewer system. ${ }^{1,2}$ Concentration of the drug residues can be assessed through analytical routines that include sample collection and preservation, followed by specific analytes separation and quantification. Benzoylecgonine (BE) and cocaine (COC) have been the most frequently investigated substances within wastewater-based epidemiology (WBE) initiatives around the world, ${ }^{3-7}$ since the former is the most abundant cocaine metabolite. Also for this reason, analytical data concerning benzoylecgonine in wastewater samples has been used as a near real-time tool to estimate cocaine consumption for a given population. ${ }^{8,9}$

Several works have explored different aspects of the WBE approach including other cocaine metabolites, ${ }^{10}$

*e-mail: ffsodre@unb.br estimation of other consumed drugs, ${ }^{10-12}$ influence of recreational events, ${ }^{13-16}$ consumption dynamics in restricted facilities, ${ }^{17-19}$ temporal and spatial variability, ${ }^{20-22}$ stability of target chemicals, ${ }^{23,24}$ refinement on estimates calculation, ${ }^{25-27}$ innovations in sample preparation and analysis, ${ }^{28-30}$ among others.

In Brazil, the first work to put the WBE approach into practice was designed to assess cocaine consumption on regions served by six wastewater treatment plants (WWTP) installed in the Brazilian Federal District (FD). ${ }^{31}$ Results revealed a consumption of $920 \mathrm{mg} \mathrm{day}^{-1} 1000$ inhabitants $^{-1}$. Recently, our group also showed higher cocaine consumption patterns in the FD during the FIFA World Cup weekend matches as well as significant crack-cocaine use in the FD through the determination of adulterants such as phenacetin and levamisole in wastewater samples. ${ }^{15}$ The application of the WBE approach to the Brazilian context provides perspectives beyond those conceived in other countries due to the widespread and large consumption of cocaine in its different forms and to the geographical location of the 
country, i.e., nearby the world largest cocaine producing countries (Bolivia, Peru and Colombia).

The WBE approach provides unique information on the frequency and mode of drug use, also allowing temporal and spatial monitoring of a drug use in different scales. ${ }^{32}$ In Brazil, our research group was the first investigating the WBE approach, although other colleagues share the same interest in determining illicit drugs in related matrices such as natural, drinking and residual waters. ${ }^{33-36}$ In the FD region, WBE studies have been carried out through a collaborative program supported by the National Institute for Advanced Analytical Science and Technology that involves the academy as well as the Forensic Chemistry Service of the Brazilian Federal Police. Thus, our group has also considered results of the Federal Police chemical profiling program based on the quantification of coca alkaloids and adulterants in seized cocaine samples. ${ }^{37}$

The major aim of this work was to assess cocaine consumption in the FD and to evaluate, for the first time in Brazil, temporal trends within a metropolitan region. We have also set up this study in order to expand the WBE approach to other Brazilian regions by assessing different sample preservation alternatives for cocaine and benzoylecgonine.

\section{Experimental}

\section{Chemicals and reagents}

Cocaine (COC) was supplied by the National Measurement Institute (Pymble, Australia). Benzoylecgonine (BE) was obtained from Lipomed (Arlesheim, Switzerland). Working solutions were prepared weekly. Both working solutions and sample extracts were prepared in water:methanol 90:10 (v/v). In order to improve analytical sensitivity, standard solutions, sample extracts and mobile phases were prepared in $0.1 \%$ HPLC grade formic acid (Fluka, Buchs, Switzerland). Methanol and acetonitrile (HPLC grade) were purchased from Tedia (Fairfield, USA) and ultrapure water $(18.2 \mathrm{M} \Omega \mathrm{cm})$ was produced by a Milli-Q Plus purification system (Millipore, Bedford, USA). Hydrochloric acid, sodium azide and formaldehyde were supplied by SigmaAldrich (Saint Louis, USA). Nitrogen for drying was supplied from White Martins, Rio de Janeiro, Brazil.

\section{Study area and sampling}

This work was carried out in Brasília, the capital of Brazil, and in the satellite cities of the metropolitan area of the Brazilian Federal District (FD), a region with a population of about 2.7 million people. Raw sewage collected in this region is treated in 16 wastewater treatment plants (WWTP), but in this work samples were collected in eight WWTP attending about $70 \%$ of the FD inhabitants (inh.): South-Wing WWTP (500,836 inh., $1.22 \mathrm{~m}^{3} \mathrm{~s}^{-1}$ ), Melchior WWTP (575,092 inh., $\left.0.84 \mathrm{~m}^{3} \mathrm{~s}^{-1}\right)$, North-Wing WWTP $\left(139,640\right.$ inh., $\left.0.57 \mathrm{~m}^{3} \mathrm{~s}^{-1}\right)$, Samambaia WWTP (203,808 inh., $\left.0.30 \mathrm{~m}^{3} \mathrm{~s}^{-1}\right)$, Gama WWTP (136,447 inh., $\left.0.20 \mathrm{~m}^{3} \mathrm{~s}^{-1}\right)$, Planaltina WWTP $(162,480$ inh., $\left.0.10 \mathrm{~m}^{3} \mathrm{~s}^{-1}\right)$, Paranoá WWTP $\left(110,980\right.$ inh., $\left.0.08 \mathrm{~m}^{3} \mathrm{~s}^{-1}\right)$ and Riacho Fundo WWTP (37,445 inh., $\left.0.05 \mathrm{~m}^{3} \mathrm{~s}^{-1}\right)$. Figure 1 shows a map of the FD with emphasis to the areas covered by the WWTPs investigated.

Sampling was carried out in the WWTPs inlets during a $24 \mathrm{~h}$ period using a refrigerated automatic water/ wastewater sampler (Teledyne Isco, Lincoln, USA), equipped with a peristaltic pump that draws wastewater aliquots based on the variable wastewater flow. During the sampling period, composite samples were stored in dark glass bottles at $4{ }^{\circ} \mathrm{C}$ and further analytical steps were carried out immediately after samples arrived at the laboratory. One $24 \mathrm{~h}$ composite sample was collected for each WWTP except for the North-Wing WWTP where sampling was also made in seven consecutive days. In this case, composite samples were immediately transported to the laboratory after each $24 \mathrm{~h}$ sampling period. This WWTP was selected for our first temporal investigation due to the higher per capita cocaine consumption in comparison with other FD regions. ${ }^{31}$

\section{Sample preparation}

Preliminary experiments, in a $2^{3}$ factorial design, were carried out to optimize some parameters that may affect the solid phase extraction (SPE), i.e., extraction solvent (methanol or methanol:acetronitrile $(40: 60, \mathrm{v} / \mathrm{v})$ ), solid phase washing step (with 5\% methanol solution and without washing), and pre-concentration extraction factor (5 or 50 times). These optimization experiments were carried out using three different solid phases cartridges in order to provide the best recovery for a spiked sewage sample containing $2.0 \mu \mathrm{g} \mathrm{L}^{-1}$ of each target analyte. Results revealed better recoveries using a polystyrene divinylbenzene sorbent with both hydrophilic and lipophilic properties with methanol:acetonitrile (40:60, v/v) as extraction solvent without the washing step. The use of diluted extracts, obtained after a pre-concentration factor of five times, revealed better recovery due to the improvement of accuracy without a pronounced matrix effect even considering an external calibration approach for quantitation. In this case, recoveries percentages increase $14.0 \pm 2.8 \%$ and $10.9 \pm 1.5 \%$ for BE and COC, respectively, 


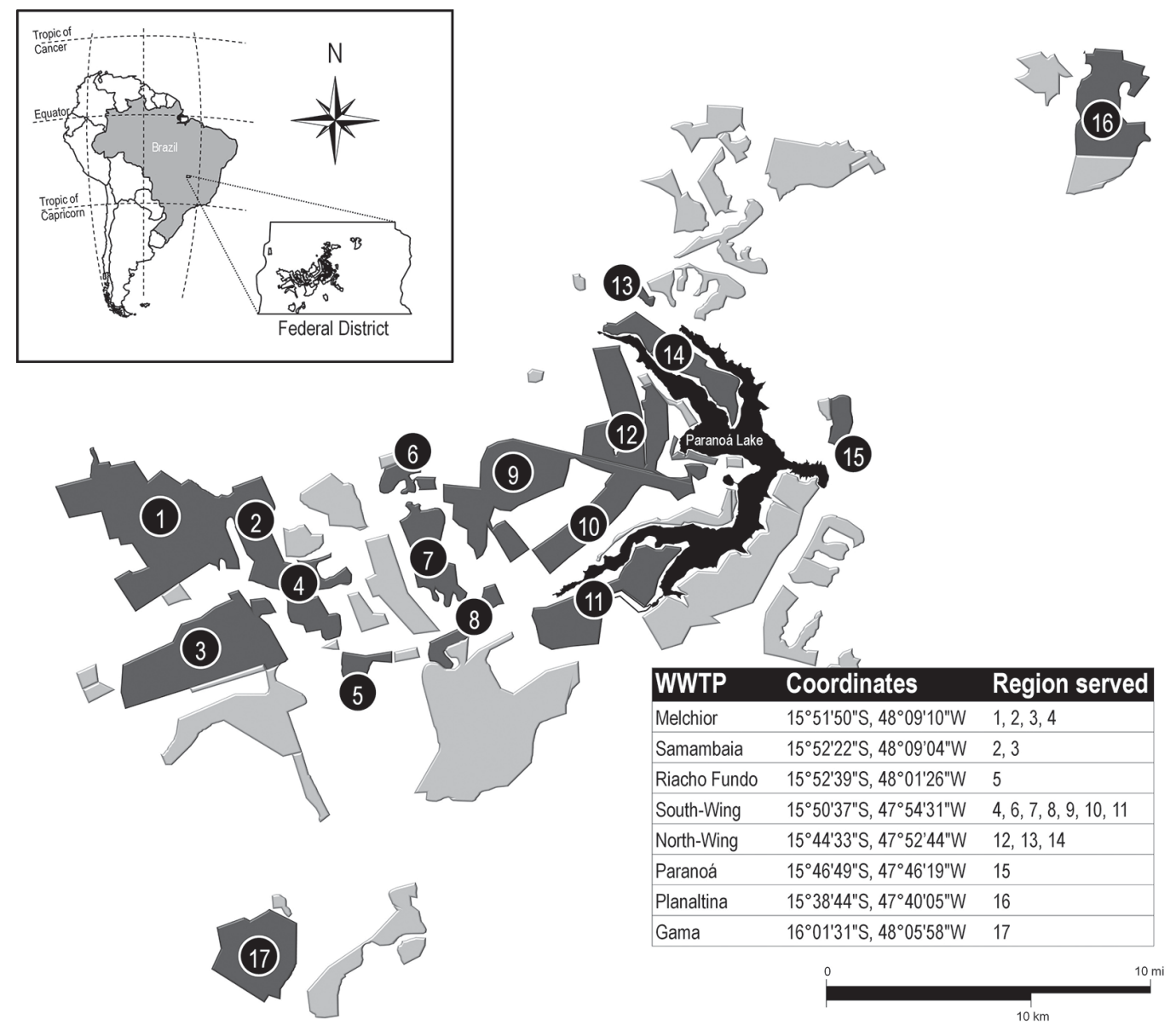

Figure 1. Map of the Federal District (FD) metropolitan region, with emphasis to the regions covered by the investigated WWTPs: (1) Ceilândia; (2) Taguatinga; (3) Samambaia; (4) Águas Claras; (5) Riacho Fundo; (6) SIA/Part Way; (7) Guará; (8) Candagolândia/Núcleo Bandeirante; (9) Sudoeste/ Octogonal/Cruzeiro; (10) Asa Sul; (11) Lago Sul; (12) Asa Norte; (13) Varjão; (14) Lago Norte; (15) Paranoá; (16) Planaltina; (17) Gama.

for the lower pre-concentration factor. Two distinct $\mathrm{pH}$ levels (samples acidification to $\mathrm{pH} 2.0$ and samples without acidification) were also evaluated during the preliminary extraction experiments.

After optimization, the extraction method was carried out as follows: aliquots of $50 \mathrm{~mL}$ of unfiltered raw sewage, in triplicates, were transferred to individual $60 \mathrm{~mL}$ syringe tubes connected in-line to Strata-X cartridges (Phenomenex, Torrance, USA) containing $500 \mathrm{mg}$ of solid sorbent phase. To avoid clogging, a portion of glass wool (Sigma-Aldrich, Schnelldorf, Germany) was placed on the top frit of each cartridge. Prior to extraction, raw samples

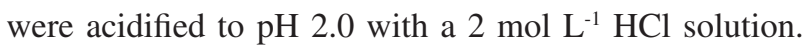
A lab-made extraction system ${ }^{38}$ was used to avoid cross contamination. The sorbent phase was conditioned with $6 \mathrm{~mL}$ of acetonitrile:methanol $(60: 40 \mathrm{v} / \mathrm{v})$ followed by $3 \mathrm{~mL}$ of a pH 2.0 ultrapure water. Samples were passed through the cartridges at a flow rate of $3 \mathrm{~mL} \mathrm{~min}^{-1}$. Cartridges were dried under a constant stream of $\mathrm{N}_{2}$ for $5 \mathrm{~min}$ and analytes were recovered under vacuum in a 12-port manifold (Visiprep, Supelco, Bellefonte, USA) with $6 \mathrm{~mL}$ of acetonitrile:methanol $(60: 40 \mathrm{v} / \mathrm{v})$ into previously cleaned glass tubes. The extracts were gently evaporated using a dry heated nitrogen evaporator (TE-09, Tecnal, Piracicaba, Brazil) and analytes were redissolved in $5.0 \mathrm{~mL}$ of a $0.1 \%$ formic acid solution prepared in 90:10 (v/v) ultrapure water:methanol mixture, i.e., the same composition of the chromatographic mobile phase in the initial of the gradient elution. Analyses were carried out in the same day.

\section{Analytes determination}

Sample extracts were analyzed using an Agilent 1200 series liquid chromatograph (LC) (Agilent Technologies, Santa Clara, USA), equipped with micro-vacuum degasser, binary pump, autosampler, 600 bar Rheodyne injection valve, and thermostated column compartment. Separation was carried out in a Zorbax SB-C18 column $(2.1 \times 30 \mathrm{~mm}$, particle size of $3.5 \mu \mathrm{m}$, Agilent Technologies, Santa Clara, USA) with gradient elution $\left(0.3 \mathrm{~mL} \mathrm{~min}^{-1}\right)$ using formic acid solutions $(0.1 \% \mathrm{v} / \mathrm{v})$ prepared in ultrapure water and in methanol as mobile phases. The gradient was achieved by 
maintaining for $4 \mathrm{~min}$ a relative methanol concentration of $10 \%$, followed by the increase to $100 \%$ in $6 \mathrm{~min}$, and held constant for another $1 \mathrm{~min}$. After readjusting to the initial conditions, the system was re-equilibrated for $7 \mathrm{~min}$. The temperature in the column compartment was kept at $25^{\circ} \mathrm{C}$ and the injection volume was $2.0 \mu \mathrm{L}$.

The chromatographic system was coupled to an Agilent 6410 triple quadrupole mass spectrometer (MS) (Agilent Technologies, Santa Clara, USA) by means of electrospray ionization source (ESI) operating in the positive mode at $3000 \mathrm{~V}$ with nitrogen as drying gas at $350{ }^{\circ} \mathrm{C}$. Mass spectrometric analyses were carried out in the multiple reaction monitoring (MRM) mode measuring the fragmentation products of the protonated molecular ions $[\mathrm{M}+\mathrm{H}]^{+}$. Table 1 shows MRM transitions for each analyte as well as instrumental and analytical parameters.

Three specific reactions were selected for each compound during the analyses, but quantification was performed considering only the most intense one (MRM1). The ratios MRM1/MRM2 and MRM1/MRM3, in terms of their signal areas, were used to guarantee specificity together with chromatographic retention times. The variability of both ratios, expressed as the standard deviation for analytical standards and sewage sample extracts, was below $10 \%$ and considered satisfactory within the analyses.

Analytes were quantified by external calibration using six-point analytical curves (coefficient of determination $\left.\left(\mathrm{R}^{2}\right)>0.99\right){ }^{39}$ The use of isotopically labeled standards is recommended in LC-MS/MS trace analysis to avoid matrix effects, increasing the accuracy of the sample preparation and quantification steps. The unavailability to such standards has led us to seek the best possible conditions to obtain high analytical recoveries. Using the optimized extraction procedure, we observe that recoveries percentages increase $14.0 \pm 2.8 \%$ and $10.9 \pm 1.5 \%$ for $\mathrm{BE}$ and $\mathrm{COC}$, respectively, for the lower pre-concentration factor tested during the preliminary experiments carried out in a $2^{3}$ factorial design. Thus, it was possible to obtain highly satisfactory recoveries (Table 1), calculated by the geometric mean obtained for eight authentic sewage samples spiked with $1000 \mathrm{ng} \mathrm{L}^{-1}$ of each analyte.

Method quantification limits (MQL) were expressed by the lower standard concentration of the analytical curves multiplied by the recovery and divided by the optimized pre-concentration factor of five times. Method detection limits (MDL) was calculated using MQL divided by the factor of 3.3. All results were compared using one-way analysis of variance (ANOVA) followed by the Tukey's test $(p<0.05)$ to evaluate significant differences between samples.

\section{Sample preservation experiments}

A composite sewage sample from the North-Wing WWTP was collected and immediately submitted, in triplicates, to the optimized solid phase extraction procedure described in the "Sample preparation" subsection. Results obtained for this sample was used as control in order to assess the effects of different conditions used for sample preservation. Thus, aliquots of the same sample, also in triplicates, were preserved using different strategies: (1) undisturbed sample, (2) sodium azide, (3) filtration through a 0.22 micrometer cellulose acetate membrane, (4) filtration through a 0.45 micrometer cellulose acetate membrane, (5) filtration through a 0.45 micrometer cellulose acetate membrane followed by acidification to $\mathrm{pH} 2.0$, (6) acidification to $\mathrm{pH} 2.0$, (7) formaldehyde and (8) solid phase extraction and analyte preservation on the sorbent phase of the cartridges until further elution. All samples, except for the control, were packed and mailed to our laboratory using the Brazilian postal service in order to submit the samples to typical transport conditions. As soon as the samples arrived in the laboratory, after three days, they were also prepared using the optimized solid phase extraction procedure. These experiments were designed to evaluate different sample preservations conditions as well as to support the expansion of the WBE approach to other

Table 1. MRM transitions monitored, instrumental and analytical parameters for each investigated analyte

\begin{tabular}{|c|c|c|c|c|c|c|c|c|c|}
\hline Analyte & $\mathrm{F} / \mathrm{V}$ & $\begin{array}{c}\text { MRM } \\
\text { transition }^{\mathrm{a}} / \mathrm{m} / \mathrm{z}\end{array}$ & $\mathrm{CE} / \mathrm{eV}$ & MRM1/MRM2b & MRM1/MRM3 ${ }^{b}$ & $\mathrm{t}_{\mathrm{R}} / \min$ & $\begin{array}{l}\text { MDL / } \\
\left(\mathrm{ng} \mathrm{L}^{-1}\right)\end{array}$ & $\begin{array}{l}\mathrm{MQL} / \\
\left(\mathrm{ng} \mathrm{L}^{-1}\right)\end{array}$ & Recovery / \% \\
\hline $\mathrm{COC}$ & 120 & $\begin{array}{c}304.2 \rightarrow 182.2 \\
304.2 \rightarrow 82.2 \\
304.2 \rightarrow 105.1\end{array}$ & $\begin{array}{l}15 \\
30 \\
30\end{array}$ & $3.9 \pm 0.3$ & $7.4 \pm 0.5$ & 8.85 & 26 & 86 & $107 \pm 4$ \\
\hline $\mathrm{BE}$ & 110 & $\begin{aligned} 290.2 & \rightarrow 168.2 \\
290.2 & \rightarrow 105.1 \\
290.2 & \rightarrow 77.2\end{aligned}$ & $\begin{array}{l}15 \\
30 \\
35\end{array}$ & $3.6 \pm 0.2$ & $7.5 \pm 0.3$ & 7.77 & 23 & 76 & $95 \pm 5$ \\
\hline
\end{tabular}

aThe first MRM transition was used for quantification, while MRM2 and MRM3 were used for confirmation; bratio between MRM areas obtained for analytical standards and investigated samples. COC: cocaine; BE: benzoylecgonine; F: fragmentor (radiofrequency energy applied in the entrance of the Agilent 6410 system); CE: collision energy; MRM: multiple reaction monitoring; $\mathrm{t}_{\mathrm{R}}$ : retention time; MDL: method detection limit; MQL: method quantification limit. 
Brazilian regions where samples transportation will be a necessary step. All results were compared using one-way ANOVA followed by the Dunnet test $(p<0.05)$ to evaluate significant differences between samples and the control.

\section{Results and Discussion}

\section{Strategies for sample preservation}

In the present work, only in-sample stability of COC and BE was investigated. Table 2 shows the results obtained during the experiments carried out to evaluate several preservation conditions for the determination of the target analytes after a period of three days under typical transport conditions practiced by the Brazilian national postal service. All results, in triplicates, were compared to those obtained in a control experiment by the Dunnett's multiple comparison test, designed to compare each number of treatments with a single control.

$\mathrm{BE}$ and $\mathrm{COC}$ levels in the control experiment, obtained through the optimized sample preparation procedure described in the "Sample preparation" sub-section, were $3124 \pm 19$ and $965 \pm 16 \mathrm{ng} \mathrm{L}^{-1}$, respectively. Significant different concentration for the former analyte was noticed for the preservation procedures based on filtration $(0.22$ and $0.45 \mu \mathrm{m}$ ) and sodium azide. These treatments, together with the undisturbed sample, also lead to significant differences on the COC levels in comparison with the control experiment.

In this work, a COC/BE ratio of $0.309 \pm 0.005$ was noticed for the control experiment, being similar to previous results obtained for sewage samples collected at the same WWTP. ${ }^{15}$ This value was also in agreement with data reported by Ratola et al..$^{40}$ where the majority of the results collected by the authors ranged from 0.25 to 0.32 . Kasprzyk-Hordern et al..$^{41}$ mentioned that about
$45 \%$ of the initial dose of consumed cocaine is excreted in urine as benzoylecgonine, while about $9 \%$ is excreted as the parent compound, leading to a $\mathrm{COC} / \mathrm{BE}$ ratio of 0.2. However, van Nuijs et al. ${ }^{9}$ suggested cutoff value of 0.75 based on the limits of $20 \%$ of BE and $15 \%$ of COC that can be excreted according to pharmacokinetics studies reported elsewhere. Thus, ratios above 0.75 indicate low rates of metabolic conversion of cocaine to benzoylecgonine, i.e., the discharge of non-consumed cocaine into the sewage system probably by losses on transport and handling ${ }^{42}$ in the streets or in clandestine facilities. In Table 2, it is possible to observe that preservation strategies based on acidification, addition of formaldehyde and stabilization on lipophilic/hydrophilic sorbent were the only ones that provided COC/BE ratios similar to the control experiment.

Figure 2 shows a comparison between the preservation strategies based on relative errors, as a measure of accuracy, calculated for $\mathrm{COC}$ and $\mathrm{BE}$ concentrations against the data generated for the control experiment.

In general, the preservation strategies led to higher relative errors for $\mathrm{COC}$ in comparison with $\mathrm{BE}$. McCall et al. ${ }^{23}$ point out that cocaine can be more efficiently hydrolyzed under environmental conditions, whereas benzoylecgonine may persist even two weeks after being released. In the undisturbed sample as well as in the preservation conditions involving filtration and sodium azide, COC concentrations strongly decreased after three days, whereas BE levels increased. In the undisturbed sample, COC levels dropped $30 \%$, while BE concentration was $11 \%$ higher in comparison to the control treatment. Castiglioni et al.$^{43}$ observed similar variation on the both analytes, i.e., $-36 \%$ for $\mathrm{COC}$ and $+14 \%$ for BE, after a period of $72 \mathrm{~h}$ at $4{ }^{\circ} \mathrm{C}$.

Cocaine highest relative errors were noticed for both preservation strategies based on filtration. This step is

Table 2. Average concentrations of cocaine and benzoylecgonine in raw sewage samples after a period of three days using several preservation conditions

\begin{tabular}{|c|c|c|c|}
\hline Preservation strategy & $\mathrm{BE} /\left(\mathrm{ng} \mathrm{L}^{-1}\right)$ & $\mathrm{COC} /\left(\mathrm{ng} \mathrm{L}^{-1}\right)$ & $\mathrm{COC} / \mathrm{BE}$ ratio \\
\hline Control & $3124 \pm 19^{\mathrm{a}}$ & $965 \pm 16^{\mathrm{a}}$ & $0.309 \pm 0.005^{\mathrm{a}}$ \\
\hline (1) Undisturbed & $3477 \pm 50^{\mathrm{a}}$ & $681 \pm 34^{\mathrm{b}}$ & $0.20 \pm 0.01^{\mathrm{b}}$ \\
\hline (2) Sodium azide & $3758 \pm 33^{b}$ & $558 \pm 37^{\mathrm{b}}$ & $0.15 \pm 0.01^{\mathrm{b}}$ \\
\hline (3) Filtration $0.22 \mu \mathrm{m}$ & $4070 \pm 16^{\mathrm{b}}$ & $135 \pm 3^{b}$ & $0.033 \pm 0.001^{\mathrm{b}}$ \\
\hline (4) Filtration $0.45 \mu \mathrm{m}$ & $4065 \pm 105^{\mathrm{b}}$ & $276 \pm 57^{\mathrm{b}}$ & $0.07 \pm 0.01^{\mathrm{b}}$ \\
\hline (5) Filtration $0.45 \mu \mathrm{m} \mathrm{pH} 2.0$ & $3430 \pm 98^{\mathrm{a}}$ & $743 \pm 175^{\mathrm{a}}$ & $0.22 \pm 0.05^{\mathrm{b}}$ \\
\hline (6) $\mathrm{pH} 2.0$ & $2994 \pm 13^{a}$ & $1070 \pm 17^{\mathrm{a}}$ & $0.357 \pm 0.006^{\mathrm{a}}$ \\
\hline (7) Formaldehyde & $2661 \pm 63^{a}$ & $778 \pm 87^{a}$ & $0.29 \pm 0.03^{\mathrm{a}}$ \\
\hline (8) SPE without elution & $2911 \pm 37^{\mathrm{a}}$ & $853 \pm 64^{\mathrm{a}}$ & $0.29 \pm 0.02^{\mathrm{a}}$ \\
\hline
\end{tabular}

BE: benzoylecgonine; COC: cocaine; SPE: solid phase extration. Means followed by the same letter do not differ by Dunnet test at $95 \%$ confidence level $(\mathrm{n}=3)$. 


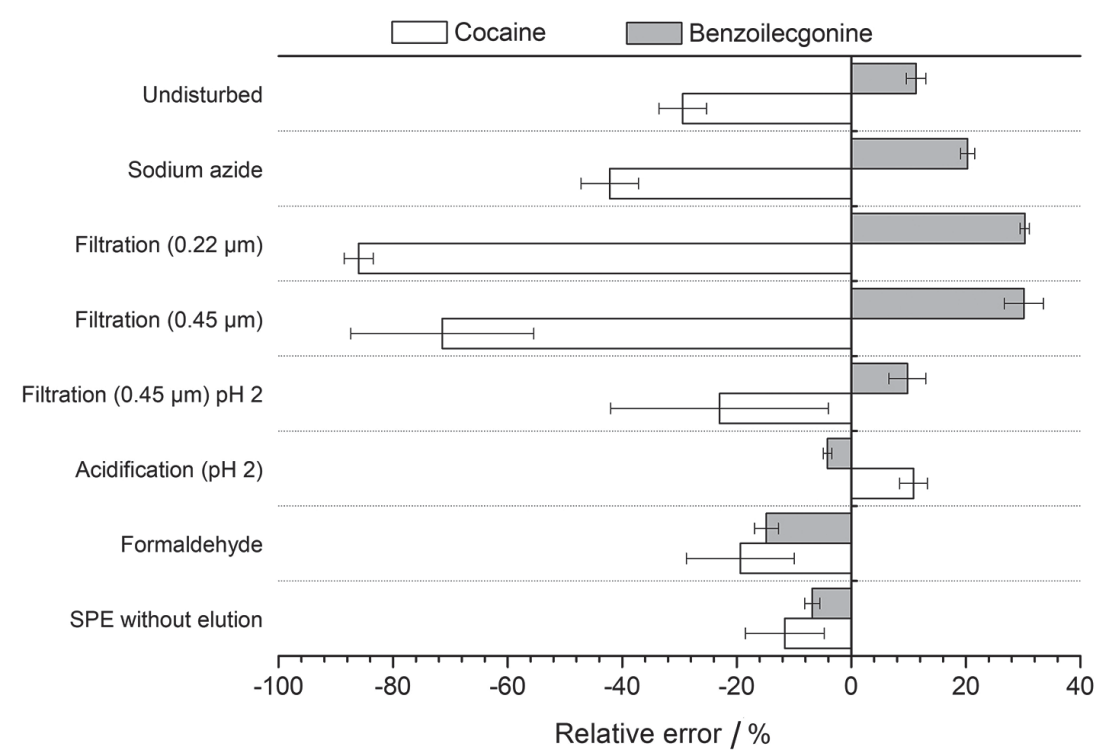

Figure 2. Preservation strategies and errors on the concentration of cocaine and benzoylecgonine in comparison with the control sample ( $\mathrm{n}=3$, after three days).

recommended during the analyses of wastewater samples to remove solid particles, being commonly used as a sample pre-treatment step preceding further extraction routines carried out immediately after sampling. ${ }^{32,44}$ Bones et al. ${ }^{45}$ suggest that retention of target analytes in microfilters results in false conclusions in the application of WBE, especially associated to COC/BE ratios. On the other hand, Metcalfe et al. ${ }^{46}$ investigated the retention of COC and $\mathrm{BE}$ in $1.5 \mu \mathrm{m}$ glass fiber filters and showed that this procedure did not alter significantly the analytical results. Similar results were obtained by Chen et al. ${ }^{47}$ using $1.6 \mu \mathrm{m}$ glass fiber filters.

Even considering the available results related to sample filtration, it is important to consider that, in our work, small pore-sized membranes were used, which could explain higher losses. However, only COC decreased after filtration, whereas BE concentrations have increased, being unlikely that retention alone explains the results observed.

In the present work, filtration was used as a sterilization procedure and not as sample pre-treatment step. Wang et al. ${ }^{48}$ point out that is generally assumed that microfilters can retain bacteria, thus being frequently used as sterilization technique. However, the authors verified the passage of significant fractions of freshwater bacterial communities through $0.45,0.22$, and even $0.1 \mu \mathrm{m}$ pore sized filters. Ghayeni et al. ${ }^{49}$ also confirmed the passage of bacteria through 0.22 and $0.1 \mu \mathrm{m}$ pore sized filters in secondary wastewater effluent samples. Thus, the variation in the concentration of $\mathrm{COC}$ and $\mathrm{BE}$ after filtration, followed by a length of three days under ambient temperature, was probably influenced by biological or chemical degradation of cocaine with partial conversion to benzoylecgonine and possibly other cocaine metabolites. ${ }^{50}$ Warner and Norman ${ }^{51}$ show that benzoylecgonine is formed under both enzymatic and non-enzymatic mechanisms. The authors also show that hydrolysis of benzoylecgonine at high $\mathrm{pH}$ is exclusive to in vitro conditions, while the action of esterases is the predominant mechanism operating in vivo.

The degradation of cocaine followed by the formation of benzoylecgonine was higher in the filtered samples in comparison with the undisturbed sample. One hypothesis to explain this behavior is that filtration may not be efficient to retain some bacterial strains that are probably more efficient to metabolize small molecules. Concomitantly, part of the cocaine may be proportionally biotransformed to benzoylecgonine. Although this hypothesis could not be proven, Wang et al. ${ }^{48}$ observed a dominant microbial population of spirillum-shaped Hylemonella gracilis strains after the microfiltration of freshwater samples. The same authors also evidenced a shape-dependent bacterial selection during the filtration process..$^{52}$ Also, preservation by acidification leads to low relative errors on the concentration of $\mathrm{COC}$ and $\mathrm{BE}$, as can be seen in Figure 2, probably by the inhibition of chemical and/or biological degradation mechanisms. We believe that the preservation procedure based on filtration followed by acidification implied in lower analyte losses in comparison with other filtration-based strategies due to the inhibition caused by the low $\mathrm{pH}$.

Preservation strategies based on the use of formaldehyde and sorbent stabilization cause the loss of both COC and $\mathrm{BE}$, indicating the absence (or the non-relevance) of interconversion mechanisms. It is also important to mention that the exposure to formaldehyde may increase 
occupational risks considering its routine use discouraging the use of this substance as preservative.

The use of SPE cartridges has been advocated as a reliable strategy for analyte storage after wastewater sampling. Castiglioni et al..$^{32}$ recommended the analyte stabilization on SPE cartridge within $12 \mathrm{~h}$ as the preferable strategy followed by freezing. Vazquez-Roig et al. ${ }^{44}$ suggested that freezing is always recommended for sample and methanolic extracts storage whereas González-Mariño et al. ${ }^{53}$ showed that dried cartridges can be stored for at least 3 months at $-20{ }^{\circ} \mathrm{C}$ without significant degradation or interconversion reactions of illicit drugs. Figure 2 shows that cocaine and benzoylecgonine stabilization on the SPE sorbent was efficient even after three days at ambient temperature. Under these conditions it was noticed a relative loss of $12 \%$ of $\mathrm{COC}$ and $7 \%$ of $\mathrm{BE}$.

Acidification to $\mathrm{pH} 2.0$ presented the smallest relative errors for COC $(11 \%)$ and BE $(4 \%)$ in comparison with the control sample and, therefore, can be applied in a future expansion of the WBE approach to other places in Brazil, an initiative that would demand samples exchange throughout the country. Previous studies also show that $\mathrm{pH}$ is the most important factor to improve the stability of cocaine and benzoylecgonine when wastewater is acidified. ${ }^{54,55}$ Moreover, $\mathrm{pH}$ correction can be easily made in non-laboratory environments and is easier than the use of SPE cartridges, since conditioning and loading may require trained personnel as well as the use of additional materials such as solvents, vacuum or peristaltic pumps. Finally, one can consider that the extraction method optimized in this work already demands sample acidification to $\mathrm{pH}$ 2.0, being even more adequate to execute this procedure before sending samples to further extraction steps at a main laboratory.

Gheorghe et al..$^{54}$ reported similar results investigating the stability of cocaine and benzoylecgonine in surface water samples. According to the authors, when samples were acidified to $\mathrm{pH} 2.0$ the concentrations of both analytes remained practically unchanged after five days of storage under different temperatures. Thus, although wastewater present different characteristics when compared to surface water samples, acidification may be also efficient for preservation. Chen et al. ${ }^{47}$ investigated different storage conditions for sewage samples and observed that transportation at ambient temperatures within 3 days is acceptable. Also, the authors aware that $\mathrm{pH}$ adjustment can be an alternative for sample preservation as long as the hydrolysis rate at low $\mathrm{pH}$ is investigated.

In Figure 2, it is also noticed that acidification was the only preservation strategy where COC levels increased as $\mathrm{BE}$ concentration becomes lower. This behavior may be explained by the equilibrium involving the interconversion of cocaine to benzoylecgonine where the spontaneous degradation of the former involves the ester hydrolysis with the replacement of the methoxy group by a hydroxyl above pH $4 .{ }^{56}$ However, we do not have enough elements to affirm that the inverse reaction is effectively occurring and this behavior will be object of further investigation within our research group.

\section{Cocaine use estimates}

Concentration of $\mathrm{COC}$ and $\mathrm{BE}$ in the WWTP samples are shown in Table 3. COC levels ranged from $519 \pm 29$ to $1260 \pm 79 \mathrm{ng} \mathrm{L}^{-1}$ whereas for its major metabolite concentration varied between $1228 \pm 98$ and $4297 \pm 298 \mathrm{ng} \mathrm{L}^{-1}$. COC/BE ratios were similar to previous reports ${ }^{15}$ except for the value of $0.71 \pm 0.06$ calculated for the Riacho Fundo WWTP. This value is in the threshold of the cutoff value of 0.75 , which indicates a relevant contribution of non-consumed drug. ${ }^{9}$

Table 3. Concentrations of cocaine and benzoylecgonine in raw sewage samples from eight WWTP of the Brazilian Federal District

\begin{tabular}{lccc}
\hline WWTP & $\mathrm{BE} /\left(\mathrm{ng} \mathrm{L}^{-1}\right)$ & $\mathrm{COC} /\left(\mathrm{ng} \mathrm{L}^{-1}\right)$ & $\mathrm{COC} / \mathrm{BE}$ ratio \\
\hline South-Wing & $1228 \pm 98$ & $520 \pm 35$ & $0.42 \pm 0.04$ \\
Melchior & $3053 \pm 205$ & $1181 \pm 80$ & $0.39 \pm 0.04$ \\
North-Wing & $1426 \pm 102$ & $519 \pm 29$ & $0.36 \pm 0.03$ \\
Samambaia & $3404 \pm 221$ & $1260 \pm 79$ & $0.37 \pm 0.03$ \\
Gama & $3338 \pm 256$ & $1175 \pm 82$ & $0.35 \pm 0.04$ \\
Planaltina & $3778 \pm 205$ & $893 \pm 58$ & $0.24 \pm 0.02$ \\
Paranoá & $4297 \pm 298$ & $1080 \pm 75$ & $0.25 \pm 0.02$ \\
Riacho Fundo & $1754 \pm 110$ & $1239 \pm 69$ & $0.71 \pm 0.06$ \\
\hline
\end{tabular}

WWTP: wastewater treatment plants; COC: cocaine; $\mathrm{BE}$ : benzoylecgonine.

The consumption of cocaine was estimated considering that the concentration of the major metabolite benzoylecgonine in the samples is multiplied by 2.33 in order to correlate with the use of free base cocaine ${ }^{2,31}$ and to compare the results with other reports including those from Brazil. However, it is important to mention that other correction factors may be used for back calculations of drug use as pointed out by Gracia-Lor et al., ${ }^{57}$ which suggest a correction factor of 3.59 based on a compilation of pharmacokinetics data related to benzoylecgonine. Figure 3 shows the cocaine consumed as drug load for each region covered by the eight WWTPs as well as per capita use of cocaine, where the amount of drug consumed was divided by the number of inhabitants served by a given WWTP. 


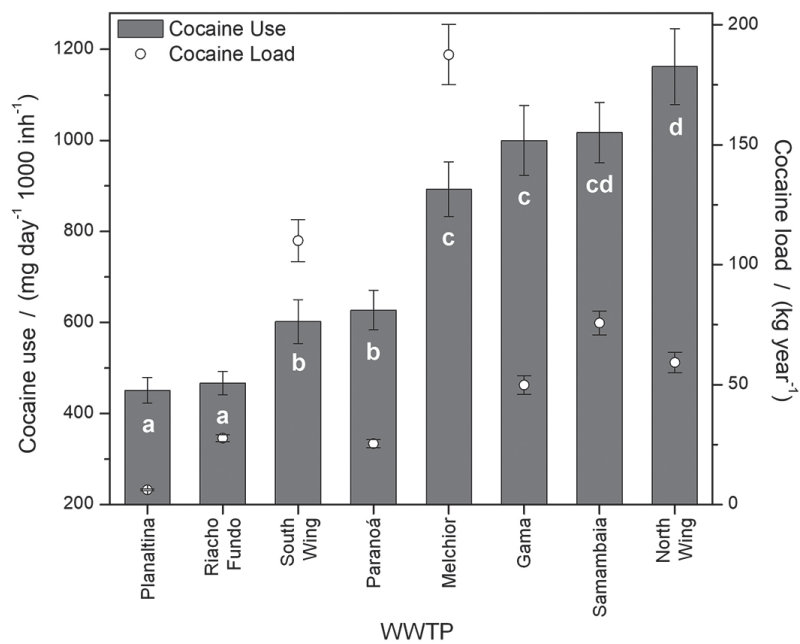

Figure 3. Cocaine loads and consumption in the Brazilian Federal District estimated by the WBDE approach in eight WWTP. Means followed by the same letter do not differ by Tukey's test at $95 \%$ confidence level.

The highest cocaine load was calculated for the Melchior WWTP $\left(188 \pm 13 \mathrm{~kg}\right.$ year $\left.{ }^{-1}\right)$ followed by the South-Wing WWTP $\left(110 \pm 9 \mathrm{~kg} \mathrm{year}^{-1}\right)$. The former WWTP serves mainly the satellite cities of Taguatinga and Ceilândia at the west portion of the FD (Figure 1), the most densely populated areas of FD. The majority of the regions covered by the South-Wing WWTP are located in the central area of the FD, although the administrative region of Águas Claras, another highly densely populated area that sends sewage to South-Wing WWTP, is positioned nearby the western Taguatinga City. Cocaine loads in the regions served by these two WWTPs accounted for approximately $55 \%$ of the consumed drug in the FD, indicating that the cocaine amount in the streets of the western portion of FD may be higher in comparison with other regions.

In view of the results of cocaine loads portrayed in Figure 3 , a human consumption of 0.54 ton of free base cocaine per year was calculated for the eight WWTP sampled. An extrapolation for the whole FD reveals a free base cocaine consumption of 0.78 ton year ${ }^{-1}$. However, a recent study from the PeQui project, coordinated by the Brazilian Federal Police, shows that the actual purity of cocaine in seized street drugs from five different states, including FD, was $49.8 \%$ with a standard deviation of $29.5 \%(n=642) .{ }^{58}$ Thus, one can consider that the actual amount of the cocaine used in the streets of FD may range from 0.98 to 3.8 tons annually, with an average value of 1.5 tons year ${ }^{-1}$. Considering the law enforcement point of view, it is important to mention that the results presented in this work can eventually be tuned to provide drug use estimates in accordance to other parallel initiatives, such as the PeQui project.

In Figure 3, per capita cocaine consumption estimates were significantly different (Tukey's test, $\alpha=0.05$ ) among the investigated WWTP, being the region covered by the North-Wing WWTP where drug use was higher per individuals. Cocaine consumption in this region was significantly different from the other investigated areas, except for the region covered by the Samambaia WWTP. The per capita drug use was also statically equal to the regions covered by Samambaia, Melchior and Gama WWTP. In a previous study, our group showed that the region covered by the Samambaia WWTP presents the highest cocaine consumption per inhabitants, followed by the area served by the North-Wing WWTP. ${ }^{31}$ Thus, even if the map of cocaine consumption has changed over the period, the two most important regions in terms of per capita drug users remained in the top of the ranking. Cocaine consumption in the region served by the North-Wing WWTP was estimated as $1162 \pm 83 \mathrm{mg}$ day $^{-1} 1000 \mathrm{inh}^{-1}$ whereas the average drug use for the entire Brazilian Federal District was projected in $777 \pm 54 \mathrm{mg} \mathrm{day}^{-1} 1000 \mathrm{inh}^{-1}$. When only the FD population of adults is considered, i.e., individuals between 15 and 64 years old, average cocaine consumption in FD is estimated as $1088 \pm 75 \mathrm{mg} \mathrm{day}^{-1} 1000 \mathrm{inh}^{-1}$ with more than 2 tons (average basis) of street-grade cocaine circulating in the FD per year.

Estimates on cocaine consumption if the FD can be compared with other data generated by the WBE approach in the world. Mastroianni et al..$^{59}$ carried out a five-year monitoring of illicit drugs in the region of Barcelona, Spain, and reveal an average cocaine use of $24 \mathrm{mg} \mathrm{day}^{-1} 1000 \mathrm{inh}^{-1}$ aging 15 to 64 years old. This value was substantially lower (45 times) in comparison to the average consumption calculated in this work for the same age group, being almost 20 times below the rate estimated for the region covered by the Planaltina WWTP, where cocaine use was the lowest observed in FD. Castiglioni et al. ${ }^{60}$ show that cocaine use was significantly higher in the East District of Milan (Italy), in comparison with other investigated areas, reaching approximately $600 \mathrm{mg} \mathrm{day}{ }^{-1} 1000 \mathrm{inh}^{-1}$, but even so being below the mean consumption rate calculated for FD. An estimated cocaine consumption up to $2000 \mathrm{mg} \mathrm{day}^{-1} 1000 \mathrm{inh}^{-1}$ was reported by Thomas et al.$^{61}$ in the European cities of Amsterdam and Antwerp. Lai et al. ${ }^{62}$ investigated cocaine consumption trends from 2009 to 2015 in South East Queensland, Australia, and showed average consumption ranging from 157 to $416 \mathrm{mg}_{\text {day }}{ }^{-1} 1000 \mathrm{inh}^{-1}$ throughout the years. However, a relatively high value (2441 mg day ${ }^{-1} 1000 \mathrm{inh}^{-1}$ ), obtained during 2012, was depicted by the authors without further details. In Fort-de France, capital of Martinique, Devault et al. ${ }^{63}$ reported a cocaine daily consumption ranging from $619 \pm 140$ to $2420 \pm 742 \mathrm{mg}$ day $^{-1} 1000 \mathrm{inh}^{-1}$ being among the highest reported in the literature, probably due to the fact that 
the region is part of the Caribbean hub of international illicit drug traffic. Cocaine consumption in the cities of Bogotá and Medellin, in Colombia, was investigated by Bijlsma et al. ${ }^{64}$ which reported a weekly average of 742 and $3022 \mathrm{mg} \mathrm{day}^{-1} 1000 \mathrm{inh}^{-1}$, respectively, using a correction factor of 3.59 .

The correction factor of 3.59 was firstly proposed by Castiglioni et $a l .^{42}$ based on studies of human urinary excretion of benzoylecgonine for different routes of administration of cocaine, i.e., intranasal, intravenous and smoked. In this case, a mean excretion of $29.2 \%$ of benzoylecgonine was calculated considering the compiled excretion data, as well as the European scenario where the predominant route of administration is intranasal (95\%), followed by smoked $(4 \%)$ and intravenous (2\%). ${ }^{65}$ Since $29.2 \%$ of the consumed cocaine (molecular weight $\left.(\mathrm{MW})=303 \mathrm{~g} \mathrm{~mol}^{-1}\right)$ is excreted in urine as benzoylecgonine $\left(\mathrm{MW}=209 \mathrm{~g} \mathrm{~mol}^{-1}\right)$, a measured benzoylecgonine excretion rate of $100 \mathrm{mg} \mathrm{day}^{-1} 1000 \mathrm{inh}^{-1}$ corresponds to $100 / 0.292 \times 303 / 289=359 \mathrm{mg}$ of cocaine consumed. The work of Devault et al., ${ }^{63}$ carried out in Martinique, explores excretion data considering the prevalence of crack consumption (smoked) as the authors assume a scenario formed by $75 \%$ of crack consumers and $25 \%$ of snorting users, leading to an excretion rate of $18.5 \%$ of benzoylecgonine.

In a previous work based on WBE approach, ${ }^{15}$ we estimate that consumption of crack in Brazil may be higher in comparison with countries such as USA and Italy, but no back-calculating was proposed. Data from the National Institute of Science and Technology for Policies on Alcohol and other Drugs ${ }^{66}$ show that 2.3 and 1.0 million adult Brazilians used intranasal and smoked cocaine, respectively. Thus, assuming a proportion of $30 \%$ of crack users in Brazil, we calculate a mean excretion of $25.0 \%$ of benzoylecgonine and, consequently, a correction factor of 4.19 to be used in future studies in Brazil. Using this country-tuned correction factor, it is possible to estimate an average cocaine consumption of $1960 \pm 135 \mathrm{mg} \mathrm{day}^{-1} 1000 \mathrm{inh}^{-1}$ in the FD (15 and 64 years old population) and an annual consumption of 3.8 tons of street-grade cocaine.

\section{Weekly variation on cocaine consumption}

Figure 4 shows the day-to-day variation of per capita cocaine consumption calculated for the region covered by the North-Wing WWTP throughout a week. Also, presents the ratio between concentrations of $\mathrm{COC}$ and $\mathrm{BE}$.

Cocaine consumption in the northern region of FD was higher in the weekends (Saturday and Sunday) in comparison

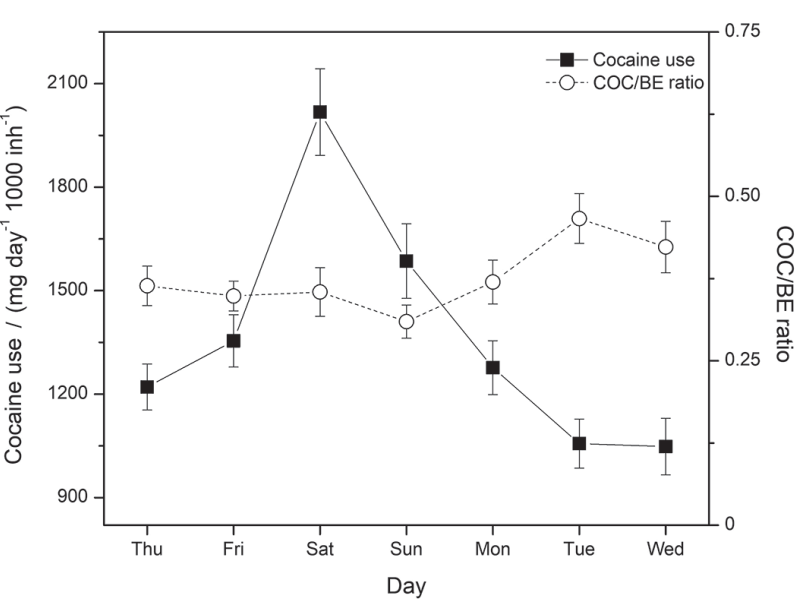

Figure 4. Weekly cocaine consumption profile in the region covered by the North-Wing WWTP.

to the weekdays. The average drug consumption during the weekend was estimated in $1800 \pm 165 \mathrm{mg} \mathrm{day}^{-1} 1000 \mathrm{inh}^{-1}$, i.e., more than $50 \%$ higher than the estimates for the weekdays $\left(1191 \pm 167 \mathrm{mg} \mathrm{day}^{-1} 1000 \mathrm{inh}^{-1}\right)$. COC/BE ratios did not vary significantly during the week and all values were below 0.75 , indicating a major metabolic origin of the drug. The increase observed in the weekend can be linked to recreational use of cocaine in association with social events. However, further studies need to be done in order to clarify this behavior, since an increase of consumed cocaine can be associated to sporadic users, that consumed not only cocaine, but other licit and illicit drugs, such as alcohol and cannabis, during social and festive events or to heavy addicted users that may experience an increase of drug use on days off.

The increase of cocaine consumption in weekends was previously reported elsewhere. Mastroianni et al. ${ }^{59}$ reported cocaine loads during weekend and weekdays of 2.3 and $1.7 \mathrm{~kg} \mathrm{day}^{-1}$, respectively, in Barcelona, Spain. Zuccato et al. ${ }^{67}$ reported temporal variations for benzoylecgonine in wastewater samples form Milan, Italy, with significantly higher concentrations occurring on Saturday, agreeing with our result. Van Nuijs et al. ${ }^{8}$ investigated cocaine consumption on 19 consecutive days in the region covered by the Brussel-Noord WWTP, in Brussels, Belgium, and observed a constant cocaine consumption during weekdays with peaks on weekends. Authors also noticed the lower cocaine consumption in the weekdays of the first investigated week (370 mg day ${ }^{-1} 1000$ inh $^{-1}$ ) in comparison to the two subsequent weeks (470 and $520 \mathrm{mg} \mathrm{day}^{-1} 1000 \mathrm{inh}^{-1}$, respectively), probably due to a holiday week in Belgium, where a significant number of inhabitants may probably leave the city. Lai et al. ${ }^{26}$ observed that consumption of cocaine in the South-East Queensland (Australia) increases during weekends and 
declines during weekdays, with higher values on Sundays. Five years later, the same group of authors carried out a nationwide survey in Australia confirming the increase of cocaine use during weekends. ${ }^{68}$ In the work carried out in France by Nefau et al., ${ }^{69}$ median drug use values of 111 and $130 \mathrm{mg} \mathrm{day}^{-1} 1000 \mathrm{inh}^{-1}$ were reported during weekends and weekdays, respectively, evidencing no clear temporal pattern. However, the authors could notice a relatively high consumption in a northern region of the country during the weekend (2434 mg day ${ }^{-1} 1000$ inh $^{-1}$ ), being almost $60 \%$ higher than the consumption estimated during the weekdays as a result of a special event occurred during sampling period, as pointed out elsewhere. ${ }^{63}$ Bijlsma et al.${ }^{64}$ investigated the presence of cocaine and benzoylecgonine in wastewater samples form the cities of Bogotá and Medellin, in Colombia, throughout a week and showed a slightly increase in benzoylecgonine loads in the weekend samples. According to the authors, Colombian consumers may use cocaine regularly and not more intensely during weekends.

\section{Conclusions}

Concentrations of COC from the eight WWTP samples ranged from 519 to $1260 \mathrm{ng} \mathrm{L}^{-1}$ and for $\mathrm{BE}$ ranged from 1228 to $4297 \mathrm{ng} \mathrm{L}^{-1}$. COC/BE ratios were all below 0.71 , indicating no relevant contribution of non-consumed drug. The highest cocaine load was calculated for the Melchior WWTP (188 kg year-1) followed by the South-Wing WWTP $\left(110 \mathrm{~kg} \mathrm{year}^{-1}\right)$. The former WWTP serves mainly the most populated satellite cities of Taguatinga and Ceilândia at the west portion of the FD, while the majority of the regions covered by the South-Wing WWTP are located in the central area of the FD. Cocaine loads in the regions served by these two WWTPs accounted for approximately $55 \%$ of the consumed drug in the FD.

The consumption of free base cocaine was estimated considering the concentration of BE. A total of human consumption of 0.54 ton of $100 \%$ pure free base cocaine per year was calculated for the eight WWTP sampled and an extrapolation for the whole FD reveals a consumption of 0.78 ton year ${ }^{-1}$. Considering the actual purity of cocaine in seized street drugs from five different states, including FD, the cocaine used in the streets of FD may have an average value of 1.5 tons year ${ }^{-1}$. The per capita cocaine consumption was higher in the region covered by the North-Wing WWTP (1162 $\mathrm{mg} \mathrm{day}^{-1} 1000 \mathrm{inh}^{-1}$ ), whereas the average drug use for the entire Brazilian Federal District was projected in $777 \mathrm{mg}$ day $^{-1} 1000 \mathrm{inh}^{-1}$. Those results evidenced one of the highest reported cocaine consumption in the world, being substantially higher than results obtained in other countries. The day-to-day variation of per capita cocaine consumption were calculated for the region covered by the North-Wing WWTP throughout a week and it was $50 \%$ higher in the weekends (Saturday and Sunday) in comparison to the weekdays.

Additional experiments, carried out to evaluate preservation, revealed that sample acidification to $\mathrm{pH} 2.0$ presents the smallest relative errors for COC $(11 \%)$ and BE $(-4 \%)$ in comparison with the control sample. This result can be useful to boost the expansion of the WBE approach to other Brazilian regions, since samples can be easily preserved and send by postal service to a main laboratory for SPE-LC-MS/MS analysis.

\section{Acknowledgments}

This work was supported by the National Institute for Advanced Analytical Science and Technology (INCTAA/FINEP/MCT 01.09.0275-00), the National Counsel of Technological and Scientific Development (CNPq 402783/2010-7) and the Federal District Research Foundation (FAPDF 193.000.916/2015).

\section{References}

1. Zuccato, E.; Castiglioni, S.; Philos. Trans. R. Soc., A 2009, 367, 3965.

2. Zuccato, E.; Chiabrando, C.; Castiglioni, S.; Calamari, D.; Bagnati, R.; Schiarea, S.; Fanelli, R.; Environ. Health 2005, 4, 14.

3. Feitosa, R. S.; Sodré, F. F.; Maldaner, A. O.; Quim. Nova 2013 , 36, 291.

4. Burgard, D. A.; Banta-Green, C.; Field, J. A.; Environ. Sci. Technol. 2014, 48, 1362.

5. Kim, K. Y.; Lai, F. Y.; Kim, H.-Y.; Thai, P. K.; Mueller, J. F.; Oh, J.-E.; Sci. Total Environ. 2015, 524, 440.

6. Kinyua, J.; Covaci, A.; Maho, W.; McCall, A.-K.; Neels, H.; van Nuijs, A. L. N.; Drug Test. Anal. 2015, 7, 812.

7. Salvatore, S.; Bramness, J. G.; Reid, M. J.; Thomas, K. V.; Harman, C.; Røislien, J.; PLoS One 2015, 10, Article e0138669.

8. van Nuijs, A. L. N.; Pecceu, B.; Theunis, L.; Dubois, N.; Charlier, C.; Jorens, P. G.; Bervoets, L.; Blust, R.; Neels, H.; Covaci, A.; Environ. Pollut. 2009, 157, 123.

9. van Nuijs, A. L. N.; Pecceu, B.; Theunis, L.; Dubois, N.; Charlier, C.; Jorens, P. G.; Bervoets, L.; Blust, R.; Meulemans, H.; Neels, H.; Covaci, A.; Addiction 2009, 104, 734.

10. van Nuijs, A. L. N.; Mougel, J.-F.; Tarcomnicu, I.; Bervoets, L.; Blust, R.; Jorens, P. G.; Neels, H.; Covaci, A.; Environ. Int. 2011, 37, 612 .

11. van Nuijs, A. L. N.; Gheorghe, A.; Jorens, P. G.; Maudens, K.; Neels, H.; Covaci, A.; Drug Test. Anal. 2014, 6, 861. 
12. Reid, M. J.; Derry, L.; Thomas, K. V.; Drug Test. Anal. 2014, $6,72$.

13. Lai, F. Y.; Bruno, R.; Hall, W.; Gartner, C.; Ort, C.; Kirkbride, P.; Prichard, J.; Thai, P. K.; Carter, S.; Mueller, J. F.; Addiction 2013, 108, 556.

14. Gerrity, D.; Trenholm, R. A.; Snyder, S. A.; Water Res. 2011, $45,5399$.

15. Sodré, F. F.; Souza, G. B.; Feitosa, R. S.; Pereira, C. E. B.; Maldaner, A. O.; J. Braz. Chem. Soc. 2017, 28, 2146.

16. Lai, F. Y.; Thai, P. K.; O’Brien, J.; Gartner, C.; Bruno, R.; Kele, B.; Ort, C.; Prichard, J.; Kirkbride, P.; Hall, W.; Carter, S.; Mueller, J. F.; Drug Alcohol Rev. 2013, 32, 594.

17. Postigo, C.; de Alda, M. L.; Barceló, D.; Environ. Int. 2011, 37, 49.

18. Brewer, A. J.; Banta-Green, C. J.; Ort, C.; Robel, A. E.; Field, J.; Drug Alcohol Rev. 2016, 35, 133.

19. Zuccato, E.; Gracia-Lor, E.; Rousis, N. I.; Parabiaghi, A.; Senta, I.; Riva, F.; Castiglioni, S.; Drug Alcohol Depend. 2017, 178, 285.

20. van Nuijs, A. L. N.; Pecceu, B.; Theunis, L.; Dubois, N.; Charlier, C.; Jorens, P. G.; Bervoets, L.; Blust, R.; Neels, H.; Covaci, A.; Water Res. 2009, 43, 1341.

21. Kinyua, J.; Anderson, T. A.; J. Forensic Sci. 2012, 57, 1349.

22. Ort, C.; van Nuijs, A. L. N.; Berset, J.-D.; Bijlsma, L.; Castiglioni, S.; Covaci, A.; de Voogt, P.; Emke, E.; FattaKassinos, D.; Griffiths, P.; Hernández, F.; González-Mariño, I.; Grabic, R.; Kasprzyk-Hordern, B.; Mastroianni, N.; Meierjohann, A.; Nefau, T.; Östman, M.; Pico, Y.; Racamonde, I.; Reid, M.; Slobodnik, J.; Terzic, S.; Thomaidis, N.; Thomas, K. V.; Addiction 2014, 109, 1338.

23. McCall, A.-K.; Bade, R.; Kinyua, J.; Lai, F. Y.; Thai, P. K.; Covaci, A.; Bijlsma, L.; van Nuijs, A. L. N.; Ort, C.; Water Res. 2016, 88, 933.

24. Mardal, M.; Kinyua, J.; Ramin, P.; Miserez, B.; Van Nuijs, A. L. N.; Covaci, A.; Meyer, M. R.; Drug Test. Anal. 2017, 9, 106.

25. Been, F.; Rossi, L.; Ort, C.; Rudaz, S.; Delémont, O.; Esseiva, P.; Delemont, O.; Esseiva, P.; Environ. Sci. Technol. 2014, 48, 8162.

26. Lai, F. Y.; Ort, C.; Gartner, C.; Carter, S.; Prichard, J.; Kirkbride, P.; Bruno, R.; Hall, W.; Eaglesham, G.; Mueller, J. F.; Water Res. 2011, 45, 4437.

27. Lai, F. Y.; Anuj, S.; Bruno, R.; Carter, S.; Gartner, C.; Hall, W.; Kirkbride, K. P.; Mueller, J. F.; O’Brien, J. W.; Prichard, J.; Thai, P. K.; Ort, C.; Environ. Sci. Technol. 2015, 49, 999.

28. Evans, S. E.; Davies, P.; Lubben, A.; Kasprzyk-Hordern, B.; Anal. Chim. Acta 2015, 882, 112.

29. Castrignanò, E.; Lubben, A.; Kasprzyk-Hordern, B.; J. Chromatogr. A 2016, 1438, 84.

30. Ryu, Y.; Reid, M. J.; Thomas, K. V.; J. Chromatogr. A 2015 , 1409, 146.

31. Maldaner, A. O.; Schmidt, L. L.; Locatelli, M. A. F.; Jardim, W. F.; Sodré, F. F.; Almeida, F. V.; Pereira, C. E. B.; Silva, C. M.; J. Braz. Chem. Soc. 2012, 23, 861.
32. Castiglioni, S.; Thomas, K. V.; Kasprzyk-Hordern, B.; Vandam, L.; Griffiths, P.; Sci. Total Environ. 2014, 487, 613.

33. Thomas, K. V.; da Silva, F. M. A.; Langford, K. H.; de Souza, A. D. L.; Nizzeto, L.; Waichman, A. V.; J. Am. Water Resour. Assoc. 2014, 50, 302.

34. Campestrini, I.; Jardim, W. F.; Sci. Total Environ. 2017, 576, 374.

35. Martins, A. F.; dos Santos, J. B.; Todeschini, B. H.; Saldanha, L. F.; da Silva, D. S.; Reichert, J. F.; Souza, D. M.; Chemosphere 2017, 170, 176.

36. Pereira, C. D. S.; Maranho, L. A.; Cortez, F. S.; Pusceddu, F. H.; Santos, A. R.; Ribeiro, D. A.; Cesar, A.; Guimarães, L. L.; Sci. Total Environ. 2016, 548, 148.

37. Zacca, J. J.; Botelho, É. D.; Vieira, M. L.; Almeida, F. L. A.; Ferreira, L. S.; Maldaner, A. O.; Sci. Justice 2014, 54, 300.

38. Sodré, F. F.; Locatelli, M. A. F.; Jardim, W. F.; Quim. Nova 2010, 33, 216.

39. Miller, J. N.; Miller, J. C.; Statistics and Chemometrics for Analytical Chemistry, $5^{\text {th }}$ ed.; Pearson: Harlow, 2005.

40. Ratola, N.; Cincinelli, A.; Alves, A.; Katsoyiannis, A.; J. Hazard. Mater. 2012, 239-240, 1.

41. Kasprzyk-Hordern, B.; Dinsdale, R. M.; Guwy, A. J.; Environ. Pollut. 2009, 157, 1773.

42. Castiglioni, S.; Bijlsma, L.; Covaci, A.; Emke, E.; Hernández, F.; Reid, M.; Ort, C.; Thomas, K. V.; van Nuijs, A. L. N.; de Voogt, P.; Zuccato, E.; Environ. Sci. Technol. 2013, 47, 1452.

43. Castiglioni, S.; Zuccato, E.; Crisci, E.; Chiabrando, C.; Fanelli, R.; Bagnati, R.; Anal. Chem. 2006, 78, 8421.

44. Vazquez-Roig, P.; Blasco, C.; Picó, Y.; TrAC, Trends Anal. Chem. 2013, 50, 65.

45. Bones, J.; Thomas, K. V.; Paull, B.; J. Environ. Monit. 2007, 9 , 701.

46. Metcalfe, C.; Tindale, K.; Li, H.; Rodayan, A.; Yargeau, V.; Environ. Pollut. 2010, 158, 3179.

47. Chen, C.; Kostakis, C.; Irvine, R. J.; Felgate, P. D.; White, J. M.; Drug Test. Anal. 2013, 5, 716.

48. Wang, Y.; Hammes, F.; Boon, N.; Egli, T.; Environ. Sci. Technol. 2007, 41, 7080.

49. Ghayeni, S. B. S.; Beatson, P. J.; Fane, A. J.; Schneider, R. P.; J. Memb. Sci. 1999, 153, 71.

50. Bosron, W. F.; Hurley, T. D.; Nat. Struct. Biol. 2002, 9, 4.

51. Warner, A.; Norman, A. B.; Ther. Drug Monit. 2000, 22, 266.

52. Wang, Y.; Hammes, F.; Düggelin, M.; Egli, T.; Environ. Sci. Technol. 2008, 42, 6749.

53. González-Mariño, I.; Quintana, J. B.; Rodríguez, I.; Cela, R.; J. Chromatogr. A 2010, 1217, 1748.

54. Gheorghe, A.; van Nuijs, A.; Pecceu, B.; Bervoets, L.; Jorens, P. G.; Blust, R.; Neels, H.; Covaci, A.; Anal. Bioanal. Chem. 2008, 391, 1309.

55. Baker, D. R.; Kasprzyk-Hordern, B.; J. Chromatogr. A 2011, $1218,8036$. 
56. Summavielle, T. In Assessing Illicit Drugs in Wastewater: Potential and Limitations of a New Monitoring Approach; Frost, N.; Griffiths, P., eds.; European Monitoring Centre for Drugs and Drug Addiction: Luxembourg, 2008, p. 35-52.

57. Gracia-Lor, E.; Zuccato, E.; Castiglioni, S.; Sci. Total Environ. 2016, 573, 1648.

58. Maldaner, A. O.; Botelho, É. D.; Zacca, J. J.; Melo, R. C. A.; Costa, J. L.; Zancanaro, I.; Oliveira, C. S. L.; Kasakoff, L. B.; Paixão, T. R. L. C.; J. Braz. Chem. Soc. 2016, 27, 719.

59. Mastroianni, N.; López-García, E.; Postigo, C.; Barceló, D.; de Alda, M. L.; Sci. Total Environ. 2017, 609, 916.

60. Castiglioni, S.; Borsotti, A.; Riva, F.; Zuccato, E.; Drug Alcohol Rev. 2016, 35, 128.

61. Thomas, K. V.; Bijlsma, L.; Castiglioni, S.; Covaci, A.; Emke, E.; Grabic, R.; Hernández, F.; Karolak, S.; Kasprzyk-Hordern, B.; Lindberg, R. H.; de Alda, M. L.; Meierjohann, A.; Ort, C.; Pico, Y.; Quintana, J. B.; Reid, M.; Rieckermann, J.; Terzic, S.; van Nuijs, A. L. N.; de Voogt, P.; Sci. Total Environ. 2012, 432, 432.

62. Lai, F. Y.; O’Brien, J. W.; Thai, P. K.; Hall, W.; Chan, G.; Bruno, R.; Ort, C.; Prichard, J.; Carter, S.; Anuj, S.; Kirkbride, K. P.; Gartner, C.; Humphries, M.; Mueller, J. F.; Sci. Total Environ. 2016, 568,803 .
63. Devault, D. A.; Néfau, T.; Pascaline, H.; Karolak, S.; Levi, Y.; Sci. Total Environ. 2014, 490, 970.

64. Bijlsma, L.; Botero-Coy, A. M.; Rincón, R. J.; Peñuela, G. A.; Hernández, F.; Sci. Total Environ. 2016, 565, 984.

65. Prinzleve, M.; Haasen, C.; Zurhold, H.; Matali, J. L.; Bruguera, E.; Gerevich, J.; Bácskai, E.; Ryder, N.; Butler, S.; Manning, V.; Gossop, M.; Pezous, A. M.; Verster, A.; Camposeragna, A.; Andersson, P.; Olsson, B.; Primorac, A.; Fischer, G.; Güttinger, F.; Rehm, J.; Krausz, M.; Eur. Addict. Res. 2004, 10, 147.

66. http://inpad.org.br/lenad/resultados/cocaina-e-crack/pressrelease/, accessed in April 2018.

67. Zuccato, E.; Chiabrando, C.; Castiglioni, S.; Bagnati, R.; Fanelli, R.; Environ. Health Perspect. 2008, 116, 1027.

68. Lai, F. Y.; O’Brien, J.; Bruno, R.; Hall, W.; Prichard, J.; Kirkbride, P.; Gartner, C.; Thai, P.; Carter, S.; Lloyd, B.; Burns, L.; Mueller, J.; Sci. Total Environ. 2016, 568, 810.

69. Nefau, T.; Karolak, S.; Castillo, L.; Boireau, V.; Levi, Y.; Sci. Total Environ. 2013, 461, 712.

Submitted: March 1, 2018

Published online: May 29, 2018 